*ak RMIS View/Frint Document Cover Sheet tow

This document was retrieved from the Documentation and Records Manaqement (DRM) ISEARCH System. It is intended for Information only and may not be the most recent or updated version. Contact a Document Service Center (see Hanford Info for locations) if you need additional retrieval information.

Accession \#: D196088839

Document \#: SD-WM-RPT-222

Title/Desc:

HAZARD CATEGORIZATION \& INTERPRETATION OF DOE GUIDANCE DOE-STD-1027-92

Pages: 23 


\begin{tabular}{|c|c|c|}
\hline $\begin{array}{l}\text { 2. To: (Receiving organization) } \\
\text { Distribution }\end{array}$ & $\begin{array}{l}\text { 3. from: (originating organization) } \\
\text { Solid Waste SAR Engineering }\end{array}$ & $\begin{array}{r}\text { 4. Related EDT No.: } \\
\text { N/A }\end{array}$ \\
\hline $\begin{array}{l}\text { 5. Proj./Prog./Dept./Div.: } \\
\text { Safety Analysis \& Nuclear } \\
\text { Engineering }\end{array}$ & $\begin{array}{l}\text { 6. Cog. Engr.: } \\
\text { D. J. Schmitt }\end{array}$ & $\begin{array}{l}\text { 7. Purchase Order Mo.: } \\
\text { N/A }\end{array}$ \\
\hline \multirow{2}{*}{\multicolumn{2}{|c|}{$\begin{array}{l}\text { 8. originotor Remarks: } \\
\text { Attached is the Hazard Categorization - Interpretation of } \\
\text { DOE Guidance DOE-STD-1027-92 document, WHC-SD-WM-RPT-222, } \\
\text { Revision } 0 \text { for approval/release. }\end{array}$}} & $\begin{array}{l}\text { 9. Equip./Component Mo.: } \\
\qquad N / A\end{array}$ \\
\hline & & $\begin{array}{c}\text { 10. System/Bldg./Facility: } \\
\text { CWC }\end{array}$ \\
\hline \multirow{3}{*}{\multicolumn{2}{|c|}{ 11. Receiver Remarks: }} & $\begin{array}{l}\text { 12. Mojor Assm. Dwg. No.: } \\
\text { N/A }\end{array}$ \\
\hline & & $\begin{array}{l}\text { 13. Permit/Permit Application No.: } \\
\text { N/A }\end{array}$ \\
\hline & & $\begin{array}{l}\text { 14. Required Response Date: } \\
\text { March 29, } 1996 \\
\end{array}$ \\
\hline
\end{tabular}

\begin{tabular}{|c|c|c|c|c|c|c|c|c|c|c|}
\hline 15. & & & DAI & SANSMIT & & & (F) & (G) & (H) & (I) \\
\hline $\begin{array}{l}\text { (A) } \\
\text { hom } \\
\text { No. }\end{array}$ & (B) Document/ & wing No. & $\begin{array}{l}\text { |C| } \\
\text { shoot } \\
\text { No. }\end{array}$ & $\begin{array}{l}\text { (D) } \\
\text { Rov. } \\
\text { No. }\end{array}$ & (E) Titho of & $\begin{array}{l}\text { ription of Dote } \\
\text { ittiod }\end{array}$ & $\begin{array}{l}\text { Approval } \\
\text { Decig- } \\
\text { nator }\end{array}$ & $\begin{array}{l}\text { Reason } \\
\text { for } \\
\text { Trant- } \\
\text { mittsil }\end{array}$ & $\begin{array}{l}\text { Origi } \\
\text { nator } \\
\text { Ditpo- } \\
\text { sition }\end{array}$ & $\begin{array}{l}\text { Rocoiv- } \\
\text { of } \\
\text { Diepo- } \\
\text { sition }\end{array}$ \\
\hline 1 & WHC-SD-WM & TT-222 & & 0 & $\begin{array}{l}\text { Hazard C } \\
\text { - Interp } \\
\text { DOE Guid } \\
1027-92\end{array}$ & $\begin{array}{l}\text { gorization } \\
\text { ation of } \\
\text { e DOE-STD- }\end{array}$ & $S$ & $4 / 1$ & & \\
\hline & & & & & & & & & & \\
\hline & & & & & & & & & & \\
\hline & & & & & & & & & & \\
\hline & & & & & & & & & & \\
\hline & & & & & & & & & & \\
\hline 16. & & & & & KEY & & & & & \\
\hline App & val Designator (F) & & Reato & Tranemi & & & Dieposit & on $(H) \&(I)$ & & \\
\hline $\begin{array}{l}\text { E, s, } \\
\text { sooe } \\
\text { Soc. } 1\end{array}$ & $\begin{array}{l}D \text { or N/A } \\
\text { C-CM-3-5. } \\
\text { i) }\end{array}$ & $\begin{array}{l}\text { 1. Approv } \\
\text { 2. Rolesue } \\
\text { 3. Informe }\end{array}$ & $\begin{array}{l}\text { 4. } R \\
\text { 5. P } \\
\text { 6. D }\end{array}$ & Ooviow & now. Roquirod) & $\begin{array}{l}\text { 1. Approved } \\
\text { 2. Approved w/e } \\
\text { 3. Disapproved }\end{array}$ & $\begin{array}{l}\text { Iment } \\
\text { omment }\end{array}$ & $\begin{array}{l}\text { 4. Roviowoc } \\
\text { 5. Roviowec } \\
\text { 6. Roceipt }\end{array}$ & $\begin{array}{l}\text { no/comm } \\
\text { w/comm } \\
\text { knowlod }\end{array}$ & \\
\hline
\end{tabular}

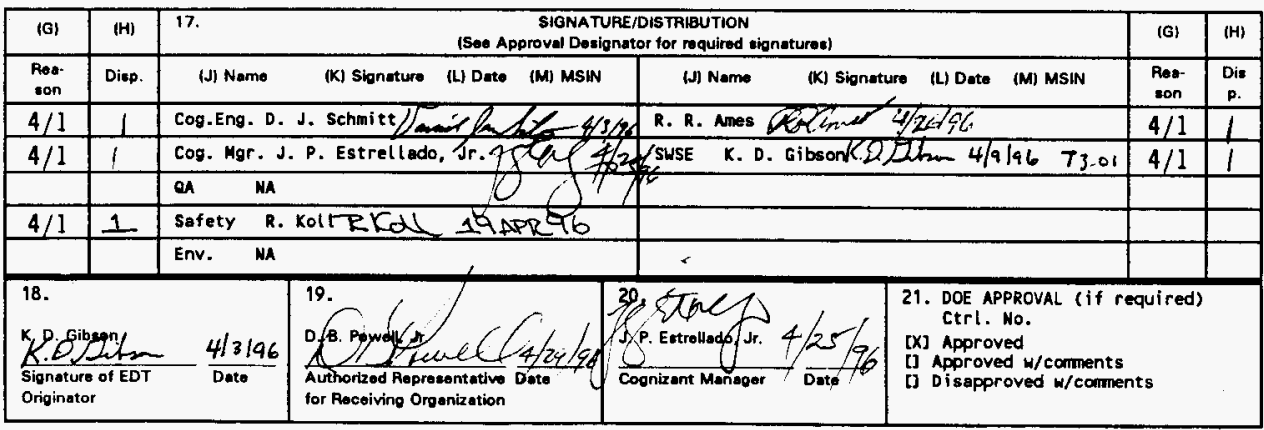




\title{
HAZARD CATEGORIZATION - INTERPRETATION OF DOE GUIDANCE DOE-STD-1027-92
}

\author{
D. J. Schmitt/R. R. Ames/D. R. Porten
}

Westinghouse Hanford Company, Richland, WA 99352

U.S. Department of Energy Contract DE-ACO6-87RL10930

$\begin{array}{lll}\text { EDT/ECN: } & 142237 & \text { UC: } 2020 \\ \text { Org Code: } & 8 M 300 & \text { Charge Code: } \\ \text { B\&R Code: } & \text { EW3130020 } & \text { Total Pages: } 20\end{array}$

Key Words: Hazard Categorization Threshold Total Quantities DOE-STD-1027-92

Abstract: This document establishes a methodology for hazard categorization, which includes modifications for threshold total quantities specified in DOE-STD-1027-92, based on facility location.

IRADEMARK DISCLAIMER. Reference herein to any specific commercial product, process, or service by trade name, trademark, manufacturer, or otherwise, does not necessarily constitute or imply its endorsement, recomnendation, or favoring by the United States Government or any agency thereof or its contractors or subcontractors.

Printed in the United states of America. To obtain copies of this document, contact: UHC/BCS Document Control Services, P.O. Box 1970, Mailstop H6-08, Richland UA 99352, Phone (509) 372-2420; Fax (509) $376-4989$.

WHC-SD-WM-RPT-222, Rev. 0

This page intentionally left blank. 
WHC-SD-WM-RPT-222, Rev. 0

\section{CONTENTS}

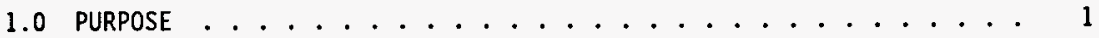

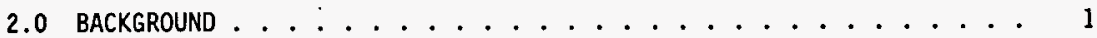

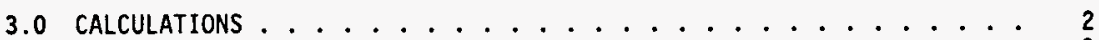
3.1 PLUME DISPERSION COEFFICIENTS ................. 3 3.2 THRESHOLD QUANTITIES $\ldots \ldots \ldots$ 3.3 THRESHOLD QUANTITY MODIFICATIONS $\ldots \ldots . . . . . . . .8$

4.0 SENSITIVITY ANALYSIS . . . . . . . . . . . . 11

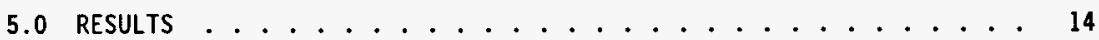

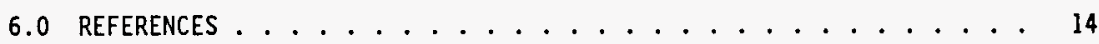




\section{LIST OF TABLES}

1 Horizontal Diffusion Parameter ................. 4

2 Vertical Diffusion Parameter ................ 4

3 Plume Dispersion Coefficient ............... 6

4 Specific Activity for Sample Calculations . . . . . . . . 7

5 Determination of Hazard Category 2 Threshold Quantities ...... 9

6 Modified Threshold Quantity Based on Different Distances . . . . . . 10

7 Correction Factor for Threshold Quantities Based on Different

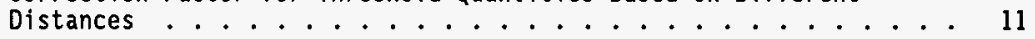

8 GXQ Program Established $X / Q$ Values . . . . . . . . . . 12

9 Modified TQ Based on 50\% Meteorological Data $x / Q$ Values . . . . . . 12

10 Modified TQ Based on $99.5 \%$ Meteorological Data $X / Q$ Values . . . . . 12

11 Percentage Reduction in Threshold Quantities Obtained with $x / Q$ Information Determined from the GXQ Code.......... 13

12 Hazard Category $x / Q \ldots \ldots 13$ 
WHC-SD-WM-RPT-222, Rev. 0

\section{LIST OF TERMS}

CEDE

CSDE

CWC

DOE

$P G$

RF

RR

SpA

TQ

$x / Q$ committed effective dose equivalent cloud shine dose equivalent

Central Waste Complex

U.S. Department of Energy

Pasquil1-Gifford

release fraction

breathing rate

specific activity

threshold quantity

atmospheric dispersion coefficience factors 
WHC-SD-WM-RPT-222, Rev. 0

This page intentionally left blank. 


\section{HAZARD CATEGORIZATION - INTERPRETATION OF DOE GUIDANCE DOE-STD-1027-92}

\subsection{PURPOSE}

The purpose of this paper is to provide assistance in interpreting DOE-STD-1027-92 by establishing the method for determining the final hazard categorization. The methodology established includes modifications to specific release fractions and facility receptor locations. The methodology provides justification for modification in specific release fractions and receptor locations. This paper provides a defensible interface with DOE-STD-1027-92, Hazard Categorization and Accident Analys is Techniques for Compliance with DOE Order 5480.23, Nuclear Safety Analysis Reports, DOE (1992) for a standardized method of validating the bases for threshold quantity (TQ) values in DOE-STD-1027-92. Additionally, new TQs based on release fractions and distances are calculated and presented in this paper.

\subsection{BACKGROUND}

DOE-STD-1027-92, Section 3.1.2, "Final Hazard Categorization," states that once a hazard analysis has been performed the final hazard categorization can be determined based on an "unmitigated release" of available hazardous material. Further, DOE-SD-1027-92 states that "for the purposes of hazard categorization 'unmitigated' is meant to consider material quantity, form, location, dispersibility, and interaction with available energy sources, but not to consider safety features (e.g., ventilation systems, fire suppression systems, etc.) which will prevent or mitigate a release." The standard indicates that the hazards analysis must provide an understanding of the material that can be released from the facility and the inventory should be compared to the TQs provided in DOE-STD-1027-92, Table A.1.

Since these TQs are derived using specific release fractions, the standard provides guidance for adjusting the TQs by dividing the ratio of the maximum potential release fraction into a standard release fraction (DOE-STD-1027-92, P. A-9). This adjustment is used to determine the final hazard categorization.

The meaning of the term "location" in Section 3.1.2 of the standard is not clearly defined. The definition of a Category 3 Hazard is "the hazard analysis shows the potential for only significant localized consequences." The potential adjustment of the Category 2 TQs using the consideration of location is not addressed in the standard. Section 4.1.1.a states that location identifies a part of a building, glovebox, or process line in which the hazardous material is present. The calculation and assumptions section (DOE-STD-1027-92, Pp. A-6 and A-7) indicates that the actual facility and the process location is significant. 
The basis for the determination of the Category 2 TQs is shown with the following equation.

$$
Q=\frac{1 \mathrm{rem}}{\left(R F \times \operatorname{SpA} \times \frac{\times}{Q} \times[(C E D E \times R R)+C S D E]\right]}
$$

where

$$
\begin{aligned}
& Q=\text { Quantity of material used as the TQ (grams) } \\
& R F=\begin{array}{l}
\text { Airborne release fraction averaged over the entire facility } \\
\text { (dimensionless) }
\end{array} \\
& S A=\text { Specific activity }(\mathrm{C} i / \mathrm{g}) \\
& X / Q=\text { Plume dispersion coefficient }\left(\mathrm{sec} / \mathrm{m}^{3}\right) \\
& C E D E=\text { Committed effective dose equivalent }(\mathrm{rem} / \mathrm{Ci}) \\
& \left.R R=\text { Respiration rate (taken to be } 3.5 \times 10^{-4} \mathrm{~m}^{3} / \mathrm{sec}\right) \\
& C S D E=\text { Cloud shine dose equivalent }\left(\mathrm{rem} \cdot \mathrm{m}^{3} / \mathrm{Ci} \cdot \mathrm{sec}\right) .
\end{aligned}
$$

The standard bases the Hazard Category 2 TQ on exceeding 1 rem effective dose equivalent to the onsite receptor using nominal meteorology.

The standard indicates that the U.S. Department of Energy (DOE) used a meteorological stability Class $D$ and a windspeed of $4.5 \mathrm{~m} / \mathrm{sec}$ in the determination of the $X / Q$ value. Using these values, the standard states that a $X / Q$ of approximately $1.0 \times 10^{-4} \mathrm{~s} / \mathrm{m}^{3}$ is established at slightly less than $300 \mathrm{~m}$. The words "approximately" and "slightly" need clarification for our purposes.

\subsection{CALCULATIONS}

This calculation is provided to explain the use of these modifications to the present hazard categorization guidance. The Central Waste Complex (CWC) is used as an example of the use of this interpretation for an actual facility. 


\subsection{PLUME DISPERSION COEFFICIENTS}

The Pasquill-Gifford (PG) system uses downwind distances to determine the diffusion parameters. Generally, this system provides reasonable estimates of the magnitude of the long-term concentrations from releases at or near ground level as depicted on PG-curves. Because of the origin of the diffusion measurements, PG-curves are strictly applicable for short-term releases (6-10 min) near ground level in uniform terrain (low roughness length) to distances less than $1 \mathrm{~km}$ (NRC 1983). Stability Class D represents a neutral classification, that can be thought of as, the atmospheric conditions associated with temperature changes between $-1.5^{\circ} \mathrm{C}$ and $-0.5^{\circ} \mathrm{C}$, caused by $100 \mathrm{~m}$ changes in height. The horizontal diffusion parameters for the $P G$ system are developed using the following equation:

$$
\sigma_{y}=\left(a_{1} \ln (x)+a_{2}\right) \cdot x
$$

where

$$
\begin{aligned}
& a_{1}=-0.0059 \text { (for stability Class } D \text { ) } \\
& a_{2}=+0.1080 \text { (for stability Class D) } \\
& x^{2}=\text { downwind distance (m). }
\end{aligned}
$$

As shown, the horizontal diffusion parameter is a nonlinear function of distance and stability class. For our purposes, however, the horizontal diffusion parameter for stability Class $D$ at different distances is calculated and presented in Table 1.

The vertical diffusion parameters for the PG system are developed using the following equation:

$$
\sigma_{2}=\frac{1}{2.15} \exp \left[b_{1}+b_{2} \ln (x)+b_{3}(\ln (x))^{2}\right]
$$

where

$$
\begin{aligned}
& b_{1}=-1.3500 \text { (for stability Class } D \text { ) } \\
& b_{2}=+0.7930 \text { (for stability Class } D \text { ) } \\
& b_{3}=+0.0022 \text { (for stability Class } D \text { ) } \\
& x^{2}=\text { downwind distance }(m) .
\end{aligned}
$$

As shown, the vertical diffusion parameter is a nonlinear function of distance and stability class. Again, for our purposes, the vertical diffusion parameter for stability Class $D$ at different distances is calculated and presented in Table 2 . 
WHC-SD-WM-RPT-222, Rev. 0

Table 1. Horizontal Diffusion Parameter.

\begin{tabular}{|c|c|}
\hline $\begin{array}{l}\text { receptor } \\
\text { distance }\end{array}$ & $\begin{array}{c}\sigma \text { for } \\
\text { stabi Y Ity Class D }\end{array}$ \\
\hline 100 & 8.08 \\
\hline 200 & 15.35 \\
\hline 300 & 22.30 \\
\hline 400 & 29.06 \\
\hline 500 & 35.67 \\
\hline 600 & 42.15 \\
\hline 700 & 48.54 \\
\hline 800 & 54.85 \\
\hline 900 & 61.08 \\
\hline 1,000 & 67.24 \\
\hline
\end{tabular}

Table 2. Vertical Diffusion Parameter.

\begin{tabular}{|c|c|}
\hline $\begin{array}{c}\text { receptor } \\
\text { distance }\end{array}$ & $\begin{array}{c}\sigma_{2} \text { for stability } \\
\text { Class } D\end{array}$ \\
\hline 100 & 4.87 \\
\hline 200 & 8.57 \\
\hline 300 & 11.93 \\
\hline 400 & 15.10 \\
\hline 500 & 18.13 \\
\hline 600 & 21.06 \\
\hline 700 & 23.90 \\
\hline 800 & 26.68 \\
\hline 900 & 29.39 \\
\hline 1,000 & 32.05 \\
\hline
\end{tabular}


Using a General Gaussian Plume Model equation, concentrations inside of a plume can be determined. The equation is as follows:

$$
\frac{x}{a}=\frac{1}{2 \pi \bar{u} \sigma \sigma_{z}} \exp \left[-\frac{y^{2}}{2 \sigma_{y}^{2}}\right]\left[\exp \left[-\frac{(z-H)^{2}}{2 \sigma_{z}^{2}}\right]+\exp \left[\frac{(z+H)^{2}}{2 \sigma_{z}^{2}}\right]\right]
$$

where

$$
\begin{aligned}
& Q=\text { release rate }(\mathrm{Ci} / \mathrm{sec}) \\
& H=\text { effective stack height }(\mathrm{m}) \\
& y=\text { lateral distance in the plume } \\
& Z=\text { vertical distance in the plume } \\
& \mathrm{U}=\text { the average centerline velocity. }
\end{aligned}
$$

However, for concentrations near the ground, the basic equation can be simplified to the following equation:

$$
\frac{X}{Q}=\frac{1}{2 \pi \bar{u} \sigma_{y} \sigma_{z}}
$$

where

$$
\begin{aligned}
& Q=\text { release rate }(\mathrm{C} i / \mathrm{sec}) \\
& y=\text { lateral distance in the plume } \\
& \mathrm{Z}=\text { vertical distance in the plume } \\
& u=\text { the average centerline velocity. }
\end{aligned}
$$

The above simplified equation is further modified to reflect a maximum building wake effect (NRC 1981 and 1982):

$$
\frac{X}{Q}=\frac{1}{3 \pi \bar{u} \sigma_{y} \sigma_{z}}
$$

where

$$
\begin{aligned}
& Q=\text { release rate }(\mathrm{C} i / \mathrm{sec}) \\
& y=\text { lateral distance in the plume } \\
& Z=\text { vertical distance in the plume } \\
& u=\text { the average centerline velocity. }
\end{aligned}
$$


The resulting plume dispersion coefficients are determined for different receptor distances (see Table 3 ).

Table 3. Plume Dispersion Coefficient.

\begin{tabular}{|c|c|}
\hline $\begin{array}{c}\text { receptor distance } \\
(\mathrm{m})\end{array}$ & $\begin{array}{c}x / Q \text { (for stability } \\
\text { Class } \mathrm{D})\left(\mathrm{s} / \mathrm{m}^{3}\right)\end{array}$ \\
\hline 100 & $5.990 \mathrm{E}-04$ \\
\hline 200 & $1.793 \mathrm{E}-04$ \\
\hline 300 & $8.860 \mathrm{E}-05$ \\
\hline 400 & $5.373 \mathrm{E}-05$ \\
\hline 500 & $3.646 \mathrm{E}-05$ \\
\hline 600 & $2.656 \mathrm{E}-05$ \\
\hline 700 & $2.032 \mathrm{E}-05$ \\
\hline 800 & $1.612 \mathrm{E}-05$ \\
\hline 900 & $1.314 \mathrm{E}-05$ \\
\hline 1,000 & $1.094 \mathrm{E}-05$ \\
\hline
\end{tabular}

\subsection{THRESHOLD QUANTITIES}

The TQs provided in the standard DOE-STD-1027-92 can be determined easily with equation [1]. To use this equation, the release fraction $X / Q$ and the specific activity of the isotope are needed. The release fraction used is standardized as shown in DOE-STD-1027-92, p. A-8. The specific activity (SpA) is calculated with equation [7].

$$
S p A=\left(\frac{\ln (2)}{t_{\frac{1}{2}}(\mathrm{sec})}\right)\left(\frac{6.02 \times 10^{23} \frac{\mathrm{dis}}{\mathrm{mol}}}{3.7 \times 10^{10} \frac{\mathrm{dis}}{\mathrm{ci}}}\right)\left[\frac{1}{\mathrm{~m}_{\mathrm{A}} \frac{\mathrm{g}}{\mathrm{mol}}}\right)
$$

where

$t_{1 / 2}=$ the half-life of the isotope in seconds

$M_{A}^{1 / 2}=$ the molecular weight of the isotope in $\mathrm{g} / \mathrm{mol}$. 
The specific activity (SpA), the committed effective dose equivalent (CEDE) per unit uptake, and cloud shine dose equivalent (CSDE) are constant for any one particular isotope. The breathing rate (RR) used is a standard used for dose calculations. In addition, Equation [1] uses a predetermined release fraction (RF). The variables present in equation [1] are the release fraction and the dispersion coefficient $(x / Q)$.

Now, equation [1] can be re-arranged to determine the $x / Q$ used in the development of the Hazard Category 2 limits 1 isted in the standard. The fission products possess a smaller $\times / 0\left(1.0 \times 10^{-4} \mathrm{~s} / \mathrm{m}^{3}\right)$ than the transuranic elements $\left(1.18 \times 10^{-4} \mathrm{~s} / \mathrm{m}^{3}\right)$. Although, it is not fully understood why the standard uses two different $x / Q$, the method used in this paper is an attempt to mirror the method used in the standard.

Specific activities are calculated for four transuranic isotopes and two fission products similar to the waste stored in the CWC. These specific activities will be used in the determination of the standard TQ values. Table 4 shows the variables used for specific isotopes in the above equation, and the specific activity calculated.

Table 4. Specific Activity for Sample Calculations.

\begin{tabular}{|c|c|c|c|}
\hline Isotope & $\begin{array}{c}\text { Molecular } \\
\text { Weight } \\
(\mathrm{g} / \mathrm{mo})\end{array}$ & $\begin{array}{c}\text { Half-Life } \\
(\mathrm{sec})\end{array}$ & $\begin{array}{c}\text { Specific } \\
\text { Activity } \\
\text { (Ci } / \mathrm{g})\end{array}$ \\
\hline${ }^{238} \mathrm{Pu}$ & 238 & $2.8 \mathrm{E}+09$ & $1.712 \mathrm{E}+01$ \\
\hline${ }^{239} \mathrm{Pu}$ & 239 & $7.6 \mathrm{E}+11$ & $6.206 \mathrm{E}-02$ \\
\hline${ }^{249} \mathrm{Pu}$ & 241 & $4.6 \mathrm{E}+08$ & $1.009 \mathrm{E}+02$ \\
\hline${ }^{241} \mathrm{Am}$ & 241 & $1.4 \mathrm{E}+10$ & $3.435 \mathrm{E}+00$ \\
\hline${ }^{137} \mathrm{Cs}$ & 137 & $9.5 \mathrm{E}+08$ & $8.652 \mathrm{E}+01$ \\
\hline${ }^{90} \mathrm{Sr}$ & 90 & $9.1 \mathrm{E}+08$ & $1.370 \mathrm{E}+02$ \\
\hline
\end{tabular}

Using a release fraction, the specific activity for an isotope, and a $x / Q$ value, one can determine the $T Q$ for a specific isotope. However, in this case, the standard release fractions (DOE-STD-1027-92, p. A-8) were used, the specific activity shown above, the TQ presented in DOE-STD-1027-92, and equation [1] to determine the $X / Q$ value. To illustrate the fact that we know the procedure for the determination of the DOE-STD-1027-92 Hazard Category 2 TQS, Table 5 was constructed to show six isotopes that are common to the waste in the CWC.

The TQ values are very accurate. It was found that a $x / Q$ of $1.0 \times 10^{-4} \mathrm{~s} / \mathrm{m}^{3}$ was established at $279 \mathrm{~m}$. Also, it was determined that a $X / Q$ of $1.18 \times 10^{-4} \mathrm{~s} / \mathrm{m}^{3}$ was necessary to produce the TQs shown in the standard. Therefore, the distance shortened somewhat to $254 \mathrm{~m}$. 
These distances reflect comments made in the standard, that the distance was somewhat less than $300 \mathrm{~m}$. This demonstrates that the procedure for the determination of the DOE-STD-1027-92, Hazard Category 2 TQS is understood. The procedure for the determination of $T Q$ values for isotopes can be extended to other isotopes not presented in the appendix of the standard $\left(\mathrm{e.g.},{ }^{244} \mathrm{Cm}\right.$, ${ }^{240} \mathrm{Pu},{ }^{442} \mathrm{Pu},{ }^{90} \mathrm{Y}$, etc.). Furthermore, there is a better understanding of how to properly modify the calculations to account for different distances and release fractions.

\subsection{THRESHOLD QUANTITY MODIFICATIONS}

Combining Equations [1], [2], [3], and [6] yields an equation for the TQ in terms of distance and release fraction as follows.

$$
Q=\psi_{0} \frac{\beta_{1} \beta_{2}}{R F}
$$

where

$$
\begin{aligned}
& \Psi_{0}=\text { the compilation of the constants } \\
& B_{1}=\text { the horizontal diffusion parameter equation } \\
& B_{2}=\text { the vertical diffusion parameter equation } \\
& R F=\text { the release fraction. }
\end{aligned}
$$

Using simple ratios, an equation can be constructed that shows how to simply modify the TQs for different distances and release fractions. The dose conversion factors are eliminated, and it should be remembered that additional modification may be warranted if there are large differences in the lung clearance classification.

$$
Q^{\prime}=Q\left(\frac{B_{1}^{\prime} B_{2}^{\prime}}{B_{1} B_{2}}\right)\left(\frac{R F}{R F^{\prime}}\right)
$$

where
$Q=$ the TQ (in grams or curies)
$B_{1}=$ the horizontal diffusion parameter equation
$B_{2}=$ the vertical diffusion parameter equation
$\mathrm{RF}^{2}=$ the release fraction
$(')=$ used to clarify the variables for specific TQs. 
Table 5. Determination of Hazard Category 2 Threshold Quantities.

\begin{tabular}{|c|c|c|c|c|c|c|c|c|}
\hline Isotope & $\begin{array}{c}\text { Effective } \\
\text { air } \\
\text { submersion } \\
\text { dose } \\
\text { (Sv } \mathrm{m}^{3} / \mathrm{Bq} \mathrm{s} \text { ) }\end{array}$ & $\begin{array}{c}\text { Effective } \\
\text { inhalation } \\
\text { dose } \\
(\mathrm{Sv} / \mathrm{Bq})\end{array}$ & $\begin{array}{c}\text { Respiration } \\
\text { rate } \\
\left(\mathrm{m}^{3} / \mathrm{s}\right)\end{array}$ & $\begin{array}{c}x / 0 \\
\left(\mathrm{~s} / \mathrm{m}^{3}\right)\end{array}$ & $\begin{array}{c}\text { Specific } \\
\text { activity } \\
(\mathrm{C} i / \mathrm{g})\end{array}$ & $\begin{array}{c}\text { Release } \\
\text { fraction } \\
\text { (unitless) }\end{array}$ & $\begin{array}{l}\text { Threshold } \\
\text { quantities } \\
\text { (g) }\end{array}$ & $\begin{array}{c}\text { Threshold } \\
\text { quantities } \\
\text { (Ci) }\end{array}$ \\
\hline${ }^{238} \mathrm{Pu}$ & $4.88 \mathrm{E}-18$ & $1.06 \mathrm{E}-04$ & $3.50 \mathrm{E}-04$ & $1.18 \mathrm{E}-04$ & $1.71 E+01$ & 0.001 & $3.60 E+00$ & $6.17 E+01$ \\
\hline${ }^{239} \mathrm{Pu}$ & $4.24 E-18$ & $1.16 \mathrm{E}-04$ & $3.50 \mathrm{E}-04$ & $1.18 \mathrm{E}-04$ & $6.21 \quad E-02$ & 0.001 & $9.09 E+02$ & $5.64 E+01$ \\
\hline${ }^{241} \mathrm{Pu}$ & $7.25 \mathrm{E}-20$ & $2.23 \mathrm{E}-06$ & $3.50 \mathrm{E}-04$ & $1.18 \mathrm{E}-04$ & $1.01 \mathrm{E}+02$ & 0.001 & $2.91 E+01$ & $2.93 E+03$ \\
\hline${ }^{241} \mathrm{Am}$ & $8.18 \mathrm{E}-16$ & $1.20 \mathrm{E}-04$ & $3.50 \mathrm{E}-04$ & $1.18 \quad E-04$ & $3.43 E+00$ & 0.001 & $1.59 E+01$ & $5.45 E+01$ \\
\hline${ }^{137} \mathrm{Cs}$ & $7.74 \quad E-18$ & $8.63 \mathrm{E}-09$ & $3.50 \mathrm{E}-04$ & $1.00 E-04$ & $8.65 E+01$ & 0.01 & $1.03 \mathrm{E}+03$ & $8.95 E+04$ \\
\hline${ }^{90} \mathrm{Sr}$ & $7.53 \mathrm{E}-18$ & $3.51 \mathrm{E}-07$ & $3.50 E-04$ & $1.00 \mathrm{E}-04$ & $1.37 \mathrm{E}+02$ & 0.001 & $1.61 \mathrm{E}+02$ & $2.20 E+04$ \\
\hline
\end{tabular}

Note: The release fraction for cesium (classified as a semi-volatile) is 0.01 . Furthermore, the $x / Q$ for the transuranic changes slightly from $1.0 \times 10^{-4}$ to $1.18 \times 10^{-4} \mathrm{~s} / \mathrm{m}^{3}$ for the determination of a similar TQ as shown in DOE-STD-1027-92, Table A.1. The CEDEs are the maximum shown for inhalation and can vary by an order of magnitude, or more for different lung clearance classes. 
An alternative form of the equation with the same limitations may be somewhat more efficient in certain circumstances. The following equation would be more useful if the $x / Q$ s are known.

$$
Q^{\prime}=Q\left[\frac{X / Q}{X / Q^{\prime}}\right]\left[\frac{R F}{R F^{\prime}}\right]
$$

where

$$
\begin{aligned}
& Q=\text { the TQ (in grams or curies) } \\
& X / Q=\text { the plume dispersion coefficient } \\
& R F=\text { the release fraction } \\
& \left({ }^{\prime}\right)=\text { used to clarify the variables for specific TQs. }
\end{aligned}
$$

With these equations, we are ready to evaluate the changes in the TQS based on distance and release fraction. Table 6 shows the change in TQ for an onsite receptor $(564 \mathrm{~m})$. The distances described in Section 3.2 are $279 \mathrm{~m}$ for fission products and $254 \mathrm{~m}$ for transuranic isotopes. Considering an onsite receptor at $564 \mathrm{~m}$ for $\mathrm{CWC}$, a fenceline receptor at 1,095 $\mathrm{m}$ and an offsite receptor at $11.7 \mathrm{~km}$, the following TQs are modified to show the effect of distance.

Table 6. Modified Threshold Quantity Based on Different Distances.

\begin{tabular}{|c|c|c|c|}
\hline Isotope & $\begin{array}{c}\text { Onsite receptor } \\
(\mathrm{C} i)\end{array}$ & $\begin{array}{c}\text { Fenceline } \\
\text { receptor } \\
(\mathrm{C} i)\end{array}$ & $\begin{array}{c}\text { Offsite receptor } \\
\text { (Ci) }\end{array}$ \\
\hline${ }^{238} \mathrm{Pu}$ & $2.47 \mathrm{E}+02$ & $7.83 \mathrm{E}+02$ & $4.71 \mathrm{E}+04$ \\
\hline${ }^{239} \mathrm{Pu}$ & $2.23 \mathrm{E}+02$ & $7.07 \mathrm{E}+02$ & $4.25 \mathrm{E}+04$ \\
\hline${ }^{241} \mathrm{Pu}$ & $1.16 \mathrm{E}+04$ & $3.66 \mathrm{E}+04$ & $2.20 \mathrm{E}+06$ \\
\hline${ }^{241} \mathrm{Am}$ & $2.19 \mathrm{E}+02$ & $6.94 \mathrm{E}+02$ & $4.18 \mathrm{E}+04$ \\
\hline${ }^{137} \mathrm{Cs}$ & $3.01 \mathrm{E}+05$ & $9.52 \mathrm{E}+05$ & $5.73 \mathrm{E}+07$ \\
\hline${ }^{90} \mathrm{Sr}$ & $7.44 \mathrm{E}+04$ & $2.35 \mathrm{E}+05$ & $1.42 \mathrm{E}+07$ \\
\hline
\end{tabular}


WHC-SD-WM-RPT-222, Rev. 0

The increase in the TQS can be determined with the following equation:

$$
\begin{gathered}
\qquad \text { diff }=\left(\frac{Q^{\prime}-Q}{Q}\right) \times 100 \% \\
\text { Correction factor }=(\% \text { diff })+1
\end{gathered}
$$

The changes in the TQs are presented in Table 7.

Table 7. Correction Factor for Threshold Quantities Based on Different Distances.

\begin{tabular}{|l|c|c|c|}
\hline \multicolumn{1}{|c|}{ Isotope } & $\begin{array}{c}\text { Onsite } \\
\text { receptor }\end{array}$ & $\begin{array}{c}\text { Fenceline } \\
\text { receptor }\end{array}$ & $\begin{array}{c}\text { offsite } \\
\text { receptor }\end{array}$ \\
\hline $\begin{array}{l}\text { Transuranic } \\
\text { isotopes }\end{array}$ & 3.99 & 12.6 & 760 \\
\hline $\begin{array}{l}\text { Fission } \\
\text { products }\end{array}$ & 3.38 & 10.7 & 644 \\
\hline
\end{tabular}

\subsection{SENSITIVITY ANALYSIS}

Acute ground level release $X / Q$ values are established with the GXQ program. These values are used to perform a simple sensitivity analysis on the method shown above. Table 8 lists the $X / Q$ values associated with different meteorological data.

From these different $X / Q$ values, TQs are modified as discussed above in Section 3.3. The results of the $50 \%$ meteorological data is shown in Table 9 . The results of the $99.5 \%$ meteorological data is shown in Table 10.

The difference between the TQs calculated above and those obtained using GXQ information can be determined with the following equation:

$$
\% \text { diff }=\left[\frac{Q^{\prime}-Q}{Q}\right] \times 100 \%
$$


Table 8. GXQ Program Established $X / Q$ Values.

\begin{tabular}{|c|c|c|c|}
\hline $\begin{array}{l}\text { Receptor } \\
\text { location }\end{array}$ & $\begin{array}{l}\text { Distance/ } \\
\text { direction }\end{array}$ & $\begin{array}{c}\text { Meteorological } \\
\text { percentile }\end{array}$ & $\begin{array}{l}x / 0 \\
\left(\mathrm{~s} / \mathrm{m}^{3}\right)\end{array}$ \\
\hline \multirow{2}{*}{ PFP } & \multirow{2}{*}{$564 \mathrm{~m} \mathrm{SE}$} & $99.5 \%$ & $1.61 \mathrm{E}-03$ \\
\hline & & $50 \%$ & $1.35 \mathrm{E}-04$ \\
\hline \multirow{2}{*}{$\begin{array}{l}\text { Closest Portion } \\
\text { of the } 200-W \\
\text { Fence-Line }\end{array}$} & \multirow{2}{*}{$1,095 \mathrm{~m} \mathrm{~W}$} & $99.5 \%$ & $4.88 \quad E-04$ \\
\hline & & $50.0 \%$ & 4.62 E-05 \\
\hline \multirow{2}{*}{ offsite } & \multirow{2}{*}{$11.7 \mathrm{~km} \mathrm{~W}$} & $99.5 \%$ & $1.76 \mathrm{E}-04$ \\
\hline & & $50.0 \%$ & $1.48 \mathrm{E}-06$ \\
\hline
\end{tabular}

PFP = plutonium finishing plant.

GXQ $=$ general purpose atmospheric dispersion code.

Table 9. Modified TQ Based on $50 \%$

Meteorological Data $x / Q$ Values.

\begin{tabular}{|c|c|c|c|}
\hline Isotope & $\begin{array}{c}\text { Onsite } \\
\text { receptor } \\
(\mathrm{Ci})\end{array}$ & $\begin{array}{c}\text { Fence } 7 \text { ine } \\
\text { receptor } \\
\text { (Ci) }\end{array}$ & $\begin{array}{c}\text { Offsite } \\
\text { receptor } \\
\text { (Ci })\end{array}$ \\
\hline${ }^{238} \mathrm{Pu}$ & $5.42 \mathrm{E}+01$ & $1.58 \mathrm{E}+02$ & $4.94 \mathrm{E}+03$ \\
\hline${ }^{239} \mathrm{Pu}$ & $4.89 \mathrm{E}+01$ & $1.43 \mathrm{E}+02$ & $4.46 \mathrm{E}+03$ \\
\hline${ }^{241} \mathrm{Pu}$ & $2.53 \mathrm{E}+03$ & $7.41 \mathrm{E}+03$ & $2.31 \mathrm{E}+05$ \\
\hline${ }^{241} \mathrm{Am}$ & $4.81 \mathrm{E}+01$ & $1.40 \mathrm{E}+02$ & $4.39 \mathrm{E}+03$ \\
\hline${ }^{137} \mathrm{Cs}$ & $6.59 \mathrm{E}+04$ & $1.93 \mathrm{E}+05$ & $6.01 \mathrm{E}+06$ \\
\hline${ }^{90} \mathrm{Sr}$ & $1.63 \mathrm{E}+04$ & $4.76 \mathrm{E}+04$ & $1.49 \mathrm{E}+06$ \\
\hline
\end{tabular}

Table 10. Modified TQ Based on $99.5 \%$ Meteorological Data $X / Q$ Values.

\begin{tabular}{|c|c|c|c|}
\hline Isotope & $\begin{array}{c}\text { Onsite } \\
\text { receptor } \\
(C i)\end{array}$ & $\begin{array}{c}\text { Fencel ine } \\
\text { receptor } \\
(C i)\end{array}$ & $\begin{array}{c}\text { Offsite } \\
\text { receptor } \\
\text { (Ci) }\end{array}$ \\
\hline${ }^{238} \mathrm{Pu}$ & $4.54 \mathrm{E}+00$ & $1.50 \mathrm{E}+01$ & $4.16 \mathrm{E}+01$ \\
\hline${ }^{239} \mathrm{Pu}$ & $4.10 \mathrm{E}+00$ & $1.35 \mathrm{E}+01$ & $3.75 \mathrm{E}+01$ \\
\hline${ }^{241} \mathrm{Pu}$ & $2.13 \mathrm{E}+02$ & $7.01 \mathrm{E}+02$ & $1.94 \mathrm{E}+03$ \\
\hline${ }^{241} \mathrm{Am}$ & $4.03 \mathrm{E}+00$ & $1.33 \mathrm{E}+01$ & $3.69 \mathrm{E}+01$ \\
\hline${ }^{137} \mathrm{Cs}$ & $5.53 \mathrm{E}+03$ & $1.82 \mathrm{E}+04$ & $5.06 \mathrm{E}+04$ \\
\hline${ }^{90} \mathrm{Sr}$ & $1.37 \mathrm{E}+03$ & $4.51 \mathrm{E}+03$ & $1.25 \mathrm{E}+04$ \\
\hline
\end{tabular}


Furthermore, the $X / Q$ values change with different receptor locations. Using different receptor locations, markedly demonstrates how distance affects the $X / Q$ values and the TQs (see Table 11 ).

Table 11. Hazard Category $x / Q$.

\begin{tabular}{|l|c|c|c|c|}
\hline \multicolumn{1}{|c|}{ Receptor } & $\begin{array}{c}\text { Distance } \\
\text { (meters) }\end{array}$ & $\begin{array}{c}\text { Direction } \\
\text { (sector) }\end{array}$ & $\begin{array}{c}x / Q \\
\left(\mathrm{~s} / \mathrm{m}^{3}\right)\end{array}$ & $\begin{array}{c}\text { Rounded } \\
\text { correction } \\
\text { factor }\end{array}$ \\
\hline Standard Distance & 254 & -- & $1.18 \mathrm{E}-04$ & 1 \\
\hline PFP Facility & 564 & SE & $2.96 \mathrm{E}-05$ & 4 \\
\hline $\begin{array}{l}\text { 200-W Fence } \\
\text { (Closest } \\
\text { Location) }\end{array}$ & 1,095 & W & $9.35 \mathrm{E}-06$ & 13 \\
\hline $\begin{array}{l}\text { ICF Kaiser } \\
\text { Maintenance Yard } \\
\text { and Building } \\
\text { 2713W }\end{array}$ & 1,200 & E & $7.97 \mathrm{E}-06$ & 15 \\
\hline $\begin{array}{l}\text { Meteorological } \\
\text { Station Annex, } \\
\text { Building 622G }\end{array}$ & 2,700 & NE & $1.96 \mathrm{E}-06$ & 60 \\
\hline
\end{tabular}

PFP = plutonium finishing plant.

"By inspection, a $X / Q$ of $1.0 \times 10^{-4} \mathrm{~s} / \mathrm{m}^{3}$ is established at $279 \mathrm{~m}$. Furthermore, a $X / Q$ of $1.18 \times 10^{-4} \mathrm{~s} / \mathrm{m}^{3}$ is necessary to produce the transuranic isotope TQs shown in the standard. Therefore, the standard distance is shortened to $254 \mathrm{~m}$. These distances reflect the comments made about the standards that the distance is somewhat less than $300 \mathrm{~m}$. The lesser distance of the two standard distances is used in the determination of the correction factors.

\subsection{RESULTS}

The methodology used in the production of the Hazard Category 2 TQs is verified and presented in the above calculations (Section 3.0). The analysis is done as consistently to that prescribed in DOE-STD-1027-92 as is possible. Determining the TQ limits with the standard's variables consistently produced the listed Hazard Category 2 TQs for the six major isotopes present in the CWC waste (100\% of the isotopes attempted in our analysis) and verifies our approach without changing release fractions or receptor locations.

An example of a modification of the TQ for a change in the release fraction is provided in the standard Attachment 1, pages A-6 through A-10. However, the change in TQs receptor location is another issue. Modification to the TQ because of facility location is allowed in the standard, but there is no definite approach described in the standard. This change is best represented through the change in the $x / Q$ value. This paper provides a 
defensible interface with DOE guidance DOE-STD-1027-92, and an established proposed methodology for standardizing changes in the TQs because of release fractions or receptor locations.

By using this information as the basis for the construction of the TQS as presented in DOE-STD-1027-92, it is determined that the GXQ program will produce TQs that are consistently conservative. The $X / Q$ values generated with the GXQ program do not produce TQs 1 isted in the standard, and as such, $X / Q s$ generated from the GXQ code should not be used in the determination of TQ.

The information presented in this paper is expected to impact future analyses and other facilities. Specifically, the establishment of a receptor location for the final hazard category determination will be needed for future analyses. The methodology presented in this paper can be applied to the production of a hazard category threshold that takes into account different release fractions and/or receptor locations, while ensuring the expected dose to the onsite receptor will be less than 1 rem for facilities designated Hazard Category 3.

\subsection{REFERENCES}

DOE, 1992, Hazard Categorization and Accident Analysis Techniques for Compliance with DOE Order 5480.23, Nuclear Safety Analysis Reports, DOE-STD-1027-92, U.S. Department of Energy, Washington, D.C.

Hey, B. E., 1993, GXQ Program Users' Guide, WHC-SD-SWD-30002, Westinghouse Hanford Company, Richland, Washington.

NRC, 1981, Technical Basis for Regulatory Guide 1.145, Atmospheric Dispersion Models for Potential Accident Consequence Assessments at Nuclear Power Plants, Regulatory Guide 2260, U.S. Nuclear Regulatory Commission, Washington, D.C.

NRC, 1982, Atmospheric Dispersion Models For Potential Accident Consequence Assessments at Nuclear Power Plants, Regulatory Guide 1.145, U.S. Nuclear Regulatory Commission, Washington, D.C.

NRC, 1983, Atmospheric Dispersion Models for Potential Accident Consequences at Nuclear Power Plants, Regulatory Guide 3332, U.S. Nuclear Regulatory Commission, Washington, D.C. 


\section{DISTRIBUTION SHEET}

\begin{tabular}{l|l|l}
\hline To & From & Page 1 of 1 \\
\cline { 3 - 3 } Distribution & Solid Waste SAR Engrg - 8M300 & Date Apri1 29, 1996 \\
\hline Project Title/Work Order & EDT No. 142237 \\
$\begin{array}{l}\text { Hazard Categorization - Interpretation of DOE Guidance DOE-STD- } \\
\text { 1027-92, WHC-SD-WM-RPT-222, Revision 0 }\end{array}$ & ECN No. NA \\
\hline
\end{tabular}

\begin{tabular}{c|c|c|c|c|c}
\hline Name & MSIN & $\begin{array}{c}\text { Text } \\
\text { With All } \\
\text { Attach. }\end{array}$ & Text Only & $\begin{array}{c}\text { Attach./ } \\
\text { Appendix } \\
\text { Only }\end{array}$ & $\begin{array}{c}\text { EDT/ECN } \\
\text { Only }\end{array}$ \\
\hline
\end{tabular}

R. R. Ames

P. J. Crane

E. G. Erpenbeck

J. P. Estrellado, Jr.

K. D. Gibson (5 copies)

R. J. Giroir

R. F. Guercia

W. H. Hamilton, Jr.

P. L. Hapke

D. J. Hart

R. M. Irwin

R. J. Koll

P. J. Macbeth

J. E. Mitchell

D. R. Porten

D. B. Powel1, Jr.

D. J. Schmitt

T. K. Teynor

D. L. Vance

Central Files (1 copies)
T4-03

T4-03

T4-50

T3-01

T3-01

T4-05

57-55

T4-05

T4-05

T3-05

T4-03

T3-05

R3-82

T4-03

A2-26

T4-03

A2-26

S7-55

T4-06

A3-88 $x$
$x$
$x$
$x$
$x$
$x$

$x$
$x$
$x$
$x$
$x$
$x$
$x$
$x$
$x$
$x$

$x$

$\hat{x}$

X 